\title{
The Arctic Ocean Melt and the Impacts in Traditional Populations: Possibilities for an International Guarantee
}

\section{Moreira da Silva $\mathrm{PH}^{1}$ and Custódio $\mathrm{MM}^{2}$}

Professor in law, Escola Superior Dom Helder Câmara, Brasil

*Corresponding author: Maraluce Maria Custódio, Master in Law and permanent professor in the Post-graduate studies at Escola Superior Dom Helder Câmara, Rua Simão Tamm, 532, Brasil, Tel: +55 31987886378; Email: maralucemc@gmail.com

\section{Research Article}

Volume 3 Issue 3

Received Date: September 04, 2020

Published Date: September 22, 2020

DOI: $10.23880 /$ abca-16000136

\section{Abstract}

The research intends to show how the melting of the Arctic Ocean, caused by the climatic collapse, affects the life of the traditional populations that inhabit the region and its ways of being influenced by the changes of the landscape and of the own structure and environmental availability. In view of this, it aims to present the environmental balance as a Human Right and, in view of this position, demonstrate the need for international mobilization to protect traditional communities that are historically more vulnerable. In order to do so, the study questions the possibility of universal jurisdiction of the Inter-American Court of Human Rights, since the litigation previously raised by the Inuit people was frustrated due to the unavailability of the non-jurisdictional countries. In addition, the possibility of litigation is also raised in the International Criminal Court, on the grounds of Ecocide. Thus, through the hypothetical-deductive method and the questions raised by Cloutier SW, et al. [1], the impacts of climate collapse on vulnerable populations will be demonstrated, with a dissertation on the imperative need of effective and sensitive international tutelage - which also justifies the research.

Keywords: Melting of the Arctic Ocean; Human rights; Climate Collapse; Traditional populations; Inter-American Court of Human Rights

${ }^{1}$ Mestrando em Direito Ambiental e Desenvolvimento Sustentável pela Escola Superior Dom Helder Câmara (ESDHC). Bacharel em Direito pela Escola Superior Dom Helder Câmara (ESDHC). Bacharelando em Letras pela Universidade Federal de Minas Gerais (UFMG).

${ }^{2}$ Doutora em Geografia pela Universidade Federal de Minas Gerais (UFMG) em programa de co-tutela com a Universidade d'Avignon. Mestre em Direito pela Universidade Federal de Minas Gerais (UFMG). Maester em Derecho Ambiental pela Universidad International de Andalucia.

\section{Introduction}

Global warming, with the consequent climatic collapses, leads to the imperative need to promote the strengthening of a perspective based on the notion of ecological balance as a human right. This is justified because, as is verified by the genesis and foundation of human rights, it is a condition for the existence of homo-sapiens on the globe-especially if we consider the concepts and imperative nature of human dignity [2]. However, the deepening of Cartesian tendencies, with a strengthening of utilitarian logic, leads the globe to the possibility of an irremediable collapse. However, the demands of production and consumption, coupled with notions of development as progress, cause the overlap of economic concerns over socio-environmental concerns.

The result of the issue is, therefore, a deepening of ecological crises with significant effects noted at the poles mainly. In the Arctic, for example, formed by a frozen plate of the ocean, the melting and thinning of the ice causes a drastic landscape and structural change, with multidimensional consequences that reach, even, the traditional populations 
that have inhabited the region for millennia. The Inuits [or Eskimos] built their culture and ways of life from the Arctic's environmental conditions. Thus, it is not necessary to speak of the said "indigenous culture" without the presence of ice - that makes travel, housing, hunting and fishing activities, for example. However, despite maintaining non-predatory behavior, they sustain the burden of deepening global warming by modern production-consumption trends.

In this sense, the research proposes to present the context of the impact of climate collapse on the life of traditional communities, questioning the need for an international protection in the sense of avoiding the disappearance of these cultures. To this end, the petition of the Inuit Circumpolar Council Canada, filed with the InterAmerican Commission on Human Rights, will be presented, which has not been successful because of the fragility of its jurisdiction over the polluters of America. From this context, and considering the socio-environmental balance as a Human Right, the question of the possibility of defending the above-mentioned universal jurisdiction of the Court, in order to guarantee the existence of the Inuit people in the Arctic, and the possibilities of litigation in the Criminal Court International. The analysis of the challenges will be carried out by legal, historical and sociological bibliographical research and by the use of the hypothetical-deductive method, with an exposition of facts and documents that point to the urgency of protecting traditional communities against the contemporary environmental impacts - which also justifies the research.

\section{The Human Right to the Environment Ecologically Balanced}

Human rights and ecological balance are symbiotic measures, since the nullity of the first impedes the full satisfaction of the second. They are rights belonging to the same niche, so that without the environmental balance life itself is unfeasible and without the demands of dignity, also the ecological well-being becomes expendable, because it is not linked to the measures of life human dignity [3]. This finding is confirmed by the findings that life is the most fundamental right among the others, considering that it was not human existence, all other rights to protect the dimensions of life would not exist. Thus, the existence of the human being on the globe must be effectively protected - above all by the strengthening of Human Rights [which also include Environmental Rights] [3]. Thus, if there is an imbalance of any of these rights, there is the disharmonization of all of them-once they are interdependent. Predation of the environment, with degradation of ecological conditions, results in the destruction of human rights, as dignity and socio-environmental well-being are threatened. It is said, therefore, that environmental multidimensionality converges on the same purpose of human rights.

In the same way, these rights are integrated, inasmuch as the signatories of the tutels [and also of the ecological problems] are mainly vulnerable [4]. The consolidation of the perception invoked would be made possible in the international field in 1972, with the Stockholm Convention, which established the environmental balance as a fundamental right and requisite for human dignity. It is the inaugural landmark of the Plan of Action for the Environment, which has given rise to 109 recommendations for a healthy environment, among other resolutions of the United Nations [5]. From the aforementioned Convention the International Environmental Law was inaugurated, which remedied doubts and omissions of the Universal Declaration of Human Rights, regarding the ecological perspectives [5]. Since then, the international community has become entangled in a new environmental perspective, based on the need for political articulation between states, governments and society [5].

The contemporary constitutionalism's reflected this tendency, setting the environmental concern as parameter for other internal laws - which represents a spirit for an effectiveness of rights. This is the case, for example, of the French Constitution which, by virtue of the preamble and Chapter XI, gave rise to the Code of the Environment - responsible for guiding environmental principles and strengthening policies for sustainable development.

Thus, it is pointed to the emergence of a paradigm in the international sphere, referring to international solidarity, whose goal is the preservation and ecological balance and Human Rights [6]. "It is this concept of solidarity that constitutes the basic essence of the human right to the environment" [6], leading the international community along the path of constant cooperation in balance among human and socio-environmental dignity.

The importance of international integration for the protection of Socio-environmental Rights is justified in view of "the insufficiency of its protection in the levels of isolated legal systems, its protection gains breadth and recognition of the international community, in order to achieve a standard of environmental protection that is reasonable" [6]. It is a powerduty of humanity. Nonetheless, it is necessary to overcome the utopian nature of the proposals, with the construction of effective and efficient policies for human and ecological protection. It is necessary to overcome the ideological plane of Human Rights, surpassing the universalistic tendencies that neglect the potential of these rights as a project of society Pinto JBM, et al. $[7,8]$ referred to this obstacle by criticizing the rationale that underlies the discussions on human rights. This is because, if the meaning of rights is the first concern, the spaces of effectiveness of these end restricted by the 
field of ideas. What is pointed out, therefore, is the need to decentralize the international concern and protection of the environment, as a way of guaranteeing concrete policies.

It is necessary to think of alternatives to overcome the bureaucratic and utopian fields, alternatives that are sufficient to reverse the consequences of intensified environmental degradation in the Industrial and Post-Second World War. The greatest challenge, in this sense, is to overcome the paradox of a development that, at the same time, as it is measured to reach standards of dignity also vilifies the rights of all orders [especially human and environmental].

\section{Arctic Melting}

The rise in greenhouse gas emissions, intensified by the Industrial Revolution, is responsible for the rise in global temperatures-especially over the past fifty years. Scientific data show that, until 2009 , the temperature rise was $0.85^{\circ} \mathrm{C}$ in the continents and $0.55^{\circ} \mathrm{C}$ in the oceans-which implies that the temperature can increase up to $6.4^{\circ}$ by 2100 , with the rise in level of the seas in one meter [9]. These are data drawn up at the request of the World Meteorological Organization of the United Nations Environment Program which was involved in establishing the Intergovernmental Panel on Climate Change in 1988 in view of the international commitment to environmental stewardship and the verification of the abnormal growing of the temperature. "The role of the IPCC is to comprehensively, objectively, openly and transparently assess relevant scientific, technical and socioeconomic information to understand the risks of human-induced climate change [10]".

The conclusions obtained point to the transfiguration of homo-sapiens into homo predator [11], since anthropogenic activity [of predatory nature] is responsible for increasing the GHG concentration in the atmosphere, which implies in climatic collapses [10]. Among the effects of rising temperatures on the globe, we must mention the occurrence of more frequent and intense storms, changes in animal habits and the melting of frozen areas [especially at the poles], with an increase in sea level. The seriousness of this is that small island developing countries (such as Tuvalu, Seychelles and Maldives) are at risk of being completely submerged by 2100 . In addition, continental countries such as Bangladesh will have more than $17 \%$ of their territory invaded by seas with invaluable socio-environmental impacts [2]. This is the effect of melting polar ice caps, which is occurring quickly. To get an idea, since 2009 the Arctic ice has tuned enough to allow the navigation of large vessels which was impossible without the risk of wreckage. "Satellite mapping has revealed a trend towards a progressive reduction of the Arctic ice sheet during the summer months in the Northern Hemisphere [12]." Thus, the Arctic landscape change implies new structures for the own planet.

In addition to the thinning of the ice, it has also been noticed the occurrence of fog of pollution [the arctic mist]. However, it is clear that there are no industries in the region this is actually the result of air pollution produced by European industrial sites, which reinforces the cross-border nature of the environment. These demands are discussed in the Arctic Council ${ }^{31}$, created by the Ottawa Declaration [composed of Canada, United States of America, Denmark, Finland, Iceland, Russia, Sweden and Norway]. The plenary session of the Council deals with environmental issues in all three dimensions, ecological, social and economic - with direct repercussions on human rights policies.

The above-mentioned debate has been reaffirmed because of the existence of traditional communities that have lived in the Arctic for millennia and which, having developed their cultures and experiences in the frozen environment, are in danger of disappearing. These are the Inuits, who bear the burden of Western production and consumption - which reinforces the vulnerability of this group.

\section{Living in the Arctic: Cultural and Human Aspects and Human Rights Violation}

The Inuit people inhabit the extreme regions of Greenland, Russia, the United States of America and Canada, having consolidated the culture and social habits from the dynamics of the life in the ice. Thus, sharing food, hunting and fishing, traditional knowledge and travel are made possible by the experience and existence on the plate of oceanic ice [1]. They are a people that are dependent on food subsistence crops, both because of the nutritional properties and the cultural and spiritual reaffirmation that involves these habits. The Inuit are "a product of the physical environment in which they live they have the tools,

\footnotetext{
1 Intergovernmental organization composed of Canada, Denmark, the United States, Finland, Norway, Sweden, Russia and Iceland, which discusses the issues of the indigenous peoples of the Arctic. (CLOUTIER, 2005) Nevertheless, although the need for protection of these communities due to their vulnerability-is clear, none of the countries populated by the Inuits are signatories to ILO Convention 169 on Indigenous and Tribal Peoples, for nonintegrationist perspective. However, non-signing of treaties is not enough to remove the obligation to protect the rights of these vulnerable people. This is because standards such as ILO Convention 169 are merely reinforcements of a paradigm already consolidated with the Universal Declaration of Human Rights. The universality of fundamental rights, embodied in the Convention as an example, binds the "international community to treat human rights globally, in a fair and equitable manner, with the same parameters and with the same emphasis." (Declaration of Vienna, 1993). Although it does not legally bind non-signatory States, international declarations on Human Rights "become an image of what the international community understands by Human Rights [16]." Thus, there is a general link - an obligatory character - in view of the fact that they concern the greater interest of mankind.
} 
techniques and knowledge perfected over thousands of years to adapt to the Arctic environment" is about a people with non-anthropocentric habits [1], in which "a relationship of complementarity prevails and a holistic view that we are part of a whole." Estimates are that up to 100,000 Inuit were living in the Arctic reserves by 2004 [13], where the organization is found in smaller communities, dispersal in the hunting season and practice of traditional whaling a major supplier of fat and protein.

In this context, the nomadic reality persists, with the exception of the groups positioned in Alaska with regard to political and religious aspects; the Inuits organize themselves around mythologies and shamanism [14]. Thus, spiritual leaders are also the political leaders, considered endowed with superhuman capacity. "They are carriers of an ambiguous character they are born, they grow, they die, but at the same time they have gifts of life and death over others, quality that make them superhuman [14]". This culture is linked to the perception of the natural environment. That is, the reasons for being of this people are closely linked to the land and the ice. It is a non- transitory reality that demands the adoption of policies that make their values and customs feasible, so that traditional peoples can be authors of their own destiny as a measure of human rights [15].

Thus, there is an obligation to comply with ILO Convention 169 on the part of all countries inhabited by the Inuits, as it is a consequence of the Universal Declaration of Human Rights, which is a measure for the dignified survival of communities, especially vulnerable communities. Thus, even though there is no formal link between countries and their duty to promote a non-integrationist perspective, it is up to these states toguarantee the dignity of their traditional peoples.

This issue is reinforced in the American perspective when the terms of the Protocol of San Salvador are invoked, which demonstrates the obligation of the signatories to promote internal and external measures for the realization of human rights [16]. Here, both the rights to work, the environmental balance, the culture and protection of "minorities" are encompassed. What is happening is that there is an attempt to promote a more ethical and solidary globalization that goes beyond the polarizations between North and South and that considers in a special way the issues related to vulnerable communities. The strengthening of this perspective guarantees the strengthening of Human Rights in an "integral, indivisible and interdependent way [17]". Nevertheless, considering the vices of reasoning that hold Human Rights in a utopian perspective, what the Inuit people have been seen is that climate change offends their own existence by the precariousness of their ways of life [16]. Thus, the international conflict was raised before the Inter-
American Commission on Human Rights (IACHR), which is responsible for "examining cases or situations of human rights violations, and action before the Inter-American Court [16]."

In this context, the president of the Inuit Circumpolar Council Canada petitioned the IACHR on the grounds that the existence of the Inuits would be threatened by the development policy of the United States of America (based on a perception of development as progress). Thus, what happened was the conduct and omissions of the country which, in addition to a predatory policy, also refuses to promote the assistance of vulnerable communities. To that end, the structure of the petition has been established by pointing outthe vulnerabilities of the Arctic, which has its ice layer in tune with global warming. In addition, the ecological, social and economic consequences of the "melting of the north" were demonstrated. Well, the elders have already verified serious climate changes such as snow reduction, melting of oceanic ice slides and erosion of the coast [1]. This reality has affected the daily chores and culture of the Inuit people, who use the ice for travel, hunting and fishing, as well as being the way of communication between groups. "Because of the loss of thickness, extent, and duration of sea ice, these traditional practices have become more dangerous, more difficult, and sometimes impossible [1]". The reduction of snow also affects the construction of the Iglus. Thus, many individuals in the community have opted for tents, which make them less safe and more exposed to the cold and storms - in addition to representing the end of important symbolism for the community.

Still about the consequences of rising temperatures in the Arctic, shamans have lost the ability to analyze the movement of clouds, so their predictions about weather are thwarted. This reality, in addition to impacting on religious crops, also makes journeys on the oceanic ice more dangerous, as storms are increasingly uncertain. It is said in the petition that the Inuits are on the verge of extinction, which sets up a clear vilification of Human Rights. This reality is anticipated by the adoption of ever more predatory positions - especially by the United States of America, which promotes the maintenance of economic power status through environmental imbalance. It is about environmental racism $^{2}$ - more than a simple environmental neglect [18]. The lack of mobilization of developed States to mitigate climate change and promote the protection of the Inuit people causes the outrage of the Universal Declaration of Human Rights, as traditional peoples are forced to "Westernize" their habits, under penalty of being dead and extinct. On the contrary, the

2 The trend of disregarding the vulnerable from the environmental perspective. That is, the systemic logic of negation of environmental spaces and blessings for black and indigenous peoples-especially. 
populations of the cities, especially of the great urban centers, have their conditions of immediate dignity met - which is done at the expense of the existence of others.

Nevertheless, while consistent with the arguments presented in the petition, the United States of America is not a part to the American Convention on Human Rights, so compliance with its recommendations is not mandatory - from a first perspective. This is confirmed by the fact that the country does not answer 21\% (twenty-one) of the Commission's letters and in the other 79\% (seventy-nine per cent) of the cases it shows a refractory position [19]. In this sense, the Inuit lawsuit ended in 2006. "The petition was rejected and the process terminated without resolution of merit, since the United States does not submit to the jurisdiction of the Inter-American Court of Human Rights [20]."

\section{International Tutue: Universal Jurisdiction of the Iachr?}

The prospects will result in the abandonment of Arctic areas by the Inuit people, since their ways of life become unfeasible every day. It is about the consolidation of a new class of refugees [the environmental ones],

However, there are no provisions expressed in the 1951 Geneva Convention defining refugees beyond concepts which include those who suffer persecution or the threat of civil and political rights. The international tutelage of socalled "environmental refugees" would only be possible by invoking the meanings of the Convention of the Organization of African Unity of 1969. What is happening, however, is that traditional communities seek ways to solve the obstacles and problems that they face, but tend to be ignored by global hegemony?.

These people have their rights vilified by progress that does not benefit them and, at the same time, they suffer from the policy of developed countries regarding the hardeningof migratory norms - which prevents refuge [22].

In addition, the issue of the Inuit people is particularly fragile, since their culture and way of life are linked to practices in the oceanic ice; however, the displacement of this population to other areas of the planet does not make it a refugee group. On the contrary, it represents, in practical terms, the extinction of a people [just as in the south it is impossible to separate the Indians from the forests, even in the north it is not possible to separate people from the environment].

In this sense, two are the ways to think about the international protection of the Inuits. The first of these concerns would be a new litigation before the Inter-American Commission on Human Rights, with referral of the case to the Inter-American Court of Human Rights. That is because it is precisely this matter that concentrates the competence to promote rights related to human dignity and analysis of violations of these [American] rights [16]. In this context, considering the extinction of a similar object in the past, it would be important to raise the preliminary concerning the universal jurisdiction of the Court. That is, its decisions must bind all the American countries, including those that are not part of the Convention above mentioned. This is because human rights are universal and binding values for all states and countries cannot evade obligations under allegations of formality [16]. Another possibility would be to claim the withdrawal of the United States from the Paris Agreement, which would legitimize the current president Donald Trump as an active pole of action in the International Criminal Court. The jurisdiction of the Court of Justice would be consolidated by the configuration of Ecocide, "a modality of ecological delinquency that violates the values of life, emotional integrity, health, aesthetics and happiness [23]."

It is said, therefore, that the Head of State of the world's greatest economic power, by adopting an omission in the face of climatic urgencies, leads to the extermination of a people [or accelerates its demise]. In this matter, following the classic tendencies of the Court, it is the role of these people (the Inuit people) to demonstrate the possibility of interpreting the Ecocide by extension to the genocide, in addition to presenting considerations about specific fraud.

Nevertheless, the invocation of German doctrine in this case would suffice to allow the admissibility of the Ecocide in the ICC by the demonstration of eventual deceit [24]. This hypothesis is strengthened by the nature of the rights that it is intended to protect - and that the trans boundary effects of the predatory policy adopted by the US President can cause in the world.

Thus, it remains to be seen that the offense against the ecological balance and the existence of certain peoples is a crime against humanity - a declaratory interpretation that is not confused with analogies and extensions [vetoed in the International Criminal Court]. In addition, the nonbinding United States of America in the Rome Statute is not enough to exclude its liability, since the UN Security Council has already recommended the application of the universal jurisdiction of the ICC [precedent of the Al-Bashir affair] [2428]. What cannot be allowed is that the country's formal non-participation in the main environmental and human rights treaties is an alibi for violation of these rights. This is because the principle of international cooperation and the universality and obligation of human rights overlaps with the absolute sovereignty of states, under the risk of a 
dictatorship of economic powers [29].

\section{Final Considerations}

The ecologically balanced environment enshrined in the Stockholm Convention of 1972 makes it possible to play the role of other rights linked to dignity insofar as it makes human existence possible on the globe [30]. However, environmental degradation, which has a major effect on climatic behavior, has threatened the integrity of human rights, as it affects the well-being of peoples and the life of communities - especially traditional ones, which are more vulnerable [30-32].

This is particularly noticeable in the case of the Inuit people who have built over the millennia a life-based culture on oceanic ice which becomes thinner and fragile with global warming. Thus, the vilification to human rights is latent. In this sense, considering the possibility of the disappearance of entire communities or the formation of large groups of environmental refugees, this research has shown the need for international protection that can go through two different paths [33]. In the first case, it refers to the defense of the universal jurisdiction of the Inter-American Court of Human Rights, which, because of its competence, cannot be neglected by countries that are not members of the treaty.

On the other hand, it has proved possible to litigate at the International Criminal Court, on the grounds of Ecocide - in the face of the current US President, who withdrew the country from the Paris Agreement. Thus, the neglect of the global ecological balance to the detriment of maintaining the status of economic power would be enough to legitimize the allegation of eventual deceit and accountability of the Court which, according to UN recommendation, has universal jurisdiction [34].

Finally, it must be said that the developed countries - especially the United States of America - cannot be endorsed in their class contempt, under penalty of living in a dictatorship of the powers. The Inuit people, as a vulnerable population [33], lack and deserve the international tutelage for the realization of the Utopia of Human and Environmental Rights - that make possible the life and dignity of the human being [30].

\section{References}

1. Cloutier SW (2005) Petition to the Inter American Commission on Human Rights Seeking Relief from violations resulting from global warming caused by acts and omissions of the United States. Canada: Inuit Circumpolar Council Canada.

2. Powers A (2012) Sea-Level Rise and Its Impact on
Vulnerable States: Four Examples. Louisiana Law Review 3(1): 151-173.

3. Del Franco RPM (2000) The human right to an adequate environment, University of deusto: Bilbao.

4. Guerra S (2010) Sustainable Development at the three major UN International conferences. In: Gomes EB, et al. (Eds.), Sustainability, development and democracy.

5. Gomes EB, Builzico B (2010) Sustainability, development and democracy.

6. Da Silva JA (2002) Constitutional Environmental Law. $4^{\text {th }}$ (Edn.), São Paulo: Malheiros.

7. Pinto JBM, Costa AB (2014) The Human Rights, Environment and Sustainability project. $2^{\text {nd }}($ Edn.), Rio de Janeiro: Lumen Juris.

8. Bertoldi MR (1992) The Human Right to a balanced environment. Florianópolis: UFSC.

9. Da Silva RWC, Da Paula BL (2009) Causa do aquecimento global: antropogênica versus natural. ARTIGO 5: 42-49.

10. Da Juras IAJM (2008) Global warming and climate change: an introduction. Plenarium 5(5): 34-46.

11. Kalof L, Fitzgerald A (2003) Reading the trophy: exploring the display of dead animals in hunting magazines. Routledge: London 18(2): 112-122.

12. Da Silva MVM (2014) The Arctic Ocean: opportunities for the new maritime boundary. Antiteses 7(13): 228-253.

13. Guimarães VMB (2018) Mythology as an element that builds sustainability. Veredas do Direito, Belo Horizonte 15(31): 271-291.

14. Da Rosa (2011) Mythology and Shamanism in the social relations of the Inuit and the Kaingang. Espaço Ameríndio, Porto Alegre 5(3): 98-122.

15. Barbosa MA (2007) Indigenous Peoples and International Organizations: Instituto do Indigenato in Brazilian Law and Self-Determination of Indigenous Peoples. Electronic Journal History in Reflection, UFG and Climate Change: The Inuits X USA case. Congress Proceedings International Human Rights Law II, Florianópolis. The general part of International Criminal Law: bases for a dogmatic elaboration. São Paulo: Revista dos Tribunais 1(2): $1-14$.

16. De Godinho FO (2006) The international protection of human rights. Belo Horizonte: Del Rey.

17. Piovesan F (2006) Human Rights and International 
Justice. Sao Paulo: Saraiva.

18. Pinto JBM (2018) Masters In Environmental Law And Sustainable Development: Structure of The Course. Dom Helder.

19. Maciel DA (2013) The United States and regional human rights protection mechanisms. Lua Nova magazine of Culture and Politics, São Paulo 90: 1-15.

20. Aleph Amin HC, De Paes AMP (2013) Human Rights and Climate Change: The Inuits X USA case. Congress Proceedings International Human Rights Law II, Florianópolis. The general part of International Criminal Law: bases for a dogmatic elaboration. São Paulo: Revista dos Tribunais, pp: 150-167.

21. Rodrigues VM, Lampier A (2017) Environmental Refugees: The Need for International Legal Protection. Nomos 37: 355-368.

22. De Claro CAB (2012) Environmental refugees: climate change, international migration and global governance. Master's Dissertation (University of Brasília).

23. De Gordilho HJS, Ravazzano F (2017) Ecocide and the international criminal court. Journal of Law Justice 31(3): 688-704.

24. Ambos K (2008) The general part of International Criminal Law: bases for a dogmatic elaboration. São Paulo: Revista dos Tribunais De Mendes FRF, Rodrigues ACR (2016) Universal Jurisdiction and its applicability in the International Criminal Court. Proceedings of the XII
National Seminar on social demands and public policies in contemporary society, Santa Cruz do, pp: 1-20.

25. Gore A (2006) The Earth and the Earth in balance. $1^{\text {st }}$ (Edn.), Trad Mário Dias Correia. São Paulo: Estrela Polar.

26. De Almedia FB (1996) General Theory of Human Rights. Porto Alegre.

27. Ambos K (2008) The general part of International Criminal Law: bases for a dogmatic elaboration. São Paulo: Revista dos Tribunais.

28. Donnelly J (1958) Human Rights and International Justice. $2^{\text {nd }}$ (Edn.), Universal human rights in theory and practice. London: Cornell University Press.

29. (1958) French Constitution: France.

30. Heidegger $M$ (1992) The fundamental concepts of metaphysics. Trad Marco Antônio Casanova. Rio de Janeiro: University Forensics.

31. Maciel PO (2017) Considerations about environmental refugees. International Journal of Environmental Law and Public Policy. Macapá 9: 61-69.

32. Marx K (1988) The capital. $3^{\text {rd }}$ (Edn.), São Paulo: Nova Cultural.

33. (1948) Declaração Universal dos Direitos Humanos.

34. Da Ramos ÉP (2011) Refugiados Ambientais: Em Busca De Reconhecimento Pelo Direito Internacional. Tese de Doutorado, pp: 1-38. 